APA E Memo No. 248

Copy No.

15

AEC Research and Development

Report

UC-81, Reactors-Power

(Special Distribution)

\title{
A CORROSION STUDY OF WELDED STAINLESS STEEL
}

\section{FUEL ELEMENTS}

C. R. Bergen

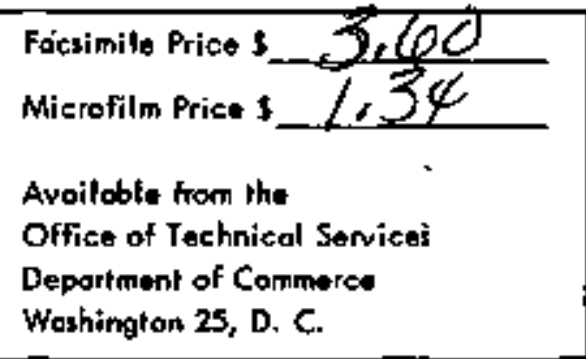

Washington 25, D. C.

Approved by:

W. S. Brown, Leader, Radiochemistry Lab

R. D. Robertson, Leader, Metallurgical Engineering Group

D. D. Foley, Head, Materials Technology Unit

Lssued: December 22, 1960

Contract No. AT(30-3)-326

with U. S. Atomic Energy Commission

New York Operations Office

ALCO PRODUCTS, INC.

Nuclear Power Engineering Department

Post Office Box 414

Schenectady 1, N. Y. 


\section{DISCLAIMER}

This report was prepared as an account of work sponsored by an agency of the United States Government. Neither the United States Government nor any agency Thereot, nor any of their employees, makes any warranty, express or implied, or assumes any legal liability or responsibility for the accuracy, completeness, or usefulness of any information, apparatus, product, or process disclosed, or represents that its use would not infringe privately owned rights. Reference herein to any specific commercial product, process, or service by trade name, trademark, manufacturer, or otherwise does not necessarily constitute or imply its endorsement, recommendation, or favoring by the United States Government or any agency thereof. The views and opinions of authors expressed herein do not necessarlly state or reflect those of the United States Government or any agency thereof. 


\section{DISCLAIMER}

Portions of this document may be illegible in electronic image products. Images are produced from the best available original document. 
AEC LEGAL NOTICE

This report was prepared as an account of Government sponsored work. Neither the United States, nor the Commission, nor any person acting on behalf of the commission:

A. Makes any warranty or representation, expressed or implied, with respect to the accuracy, completeness, or usefulness of the information contained in this report, or that the use of any information, apparatus, method, or process disclosed in this report may not infringe privately owned rights:

or

B. Assume any liabilities with respect to the use of, or for damages resulting from the use of any information, apparatus, method, or process disclosed in this report.

As used in the above, "person acting on behalf of the Commission" includes any employee or contractor of the Commission, or employee of such contractor, to the extent that such employee or contractor of the Commission, or employee of such contractor prepares, disseminates, or provides access to, any information pursuant to his employment or contract with the Commission, or his employment with such contractor.

\section{ALCO LEGAL NOTICE}

This report was prepared by Alco Products, Incorporated in the course of work under, or in connection with, Contract No. AT(30-3)-326, issued by U. S. Atomic Energy Commission, NYOO; and subject only to the rights of the United States, under the provisions of this contract, Alco Products, Incorporated makes no warranty or representation, express or implied, and shall have no liability with respect to this report or any of its contents or with respect to the use thereof or with respect to whether any such use will infringe the rights of others. 


\section{DISTRIBUTION}

COPIES

1 - 2 New York Operations Office

U. S. Atomic Energy Commission

376 Hudson Street

New York 14, New York

Attn: Chief, Army Reactors Branch, NYOO

3 - 5 U. S. Atomic Energy Commission

Washington 25, D. C.

Attn: Chief, Water Systems Project Branch (Army Reactors) Division of Reactors Development

Mail Station F-311

6

U. S. Atomic Energy Commission

Chief Patents Branch

Washington 25, D. C.

Attn: Roland A. Anderson

7 U. S. Atomic Energy Commission

Chief, New York Patent Group

Brookhaven National Laboratory

Upton, New York

Attn: Harman Potter

8

U. S. Atomic Energy Commission

Idaho Operations Office

P.O. Box 2108

Idaho Falls, Idaho

Attn: Director Division of Miltary Reactors

9 - 11 Nuclear Power Field Office

USAERDL

Fort Belvoir, Virginia

Attn: Chief, Nuclear Power Field Office 


\section{DISTRIBUTION (CONT'D)}

\section{COPIES}

12 Union Carbide Nuclear Corporation

Oak Ridge National Laboratory

Y-12 Building 9704-1

P.0. Box "Y"

Oak Ridge, Tennessee

Attn: A. L. Boch

13 The Martin Company

P.O. Box 5042

Middle River, Maryland

Attn: AEC Contract Document Custodian

14 Combustion Engineering, Inc.

P. O. Box 2558

Idaho Falls, Idaho

Attn: Mr. W. B. Allred, Project Manager SL-1

$15-17$ U. S. Atomic Energy Commission

Reference Branch

Technical Information Services Extension

P.O. Box 62

Oak Ridge, Tennessee

18 U. S. Atomic Energy Commission

Washington $25, \mathrm{D}$. C.

Attn: Chief, Evaluation and Planning Branch

Civilian Reactors, Division of Reactors Development Mail Station F-311

19 Commander, Air Force Special Weapons Center (AFSWC)

Albuquerque, New Mexico

Attn: S. W. V. 


\section{DISTRIBUTION (CONT'D)}

\section{COPIES}

20 - 21 Alco Products, Inc.

P. O. Box 145

Ft. Belvoir, Va.

Attn: H. L. 'Weinberg

$22-45$ Alco Products, Inc.

Post Office Box 414

Schenectady, New York

Attn:

22

23

24

25

26

27

28

29

30
K. Kasschau

J. Gronan

E. B. Gunyou

W. K. Stromquist

H. L. Hoover

D. D. Foley

J. G. Gallagher

J. F. Haines

W. S. Brown
31

32

33

34

35

36

$37-39$

$40-45$
G. P. Pancer

R. D. Robertson

R. E. Williams

C. R. Bergen

R. A. Shaw

C. A. Bergmann

Radiochem Lab File

NPED FILE 


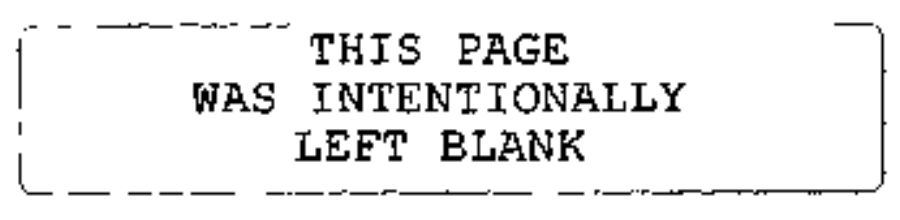




\section{ABSTRACT}

This report covers fuel element corrosion studies conducted from April, 1959 through July, 1960, designed to aid in selecting and evaluating SM-2 fuel element welding techniques. Tests on type 347 ss plate type fuel elements welded by the selected tungsten inert gas technique, showed good corrosion integrity of specimens under a variety of conditions including a 500-hr test under simulated SM-2 conditions of flow and coolant chemistry. 


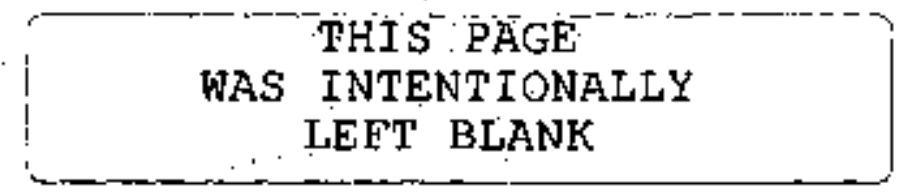


1.0 SUMMARY - 0

2.0 INTRODUCTION

2.1 Weiding Techniques

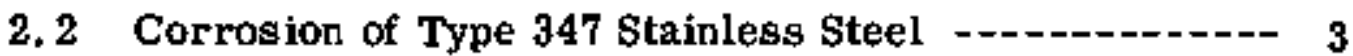

3.0 EXPERIMENTAL WORK

3.1 Equipment -

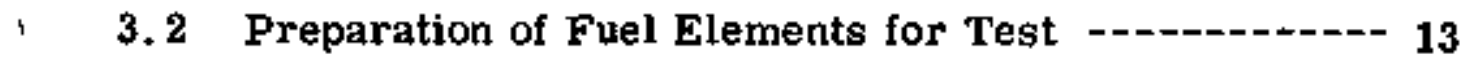

3.3 Water Chemistry -... 14

3.4 Test Procedures - 19

4. 0 TEST RESULTS AND CONCLUSIONS -

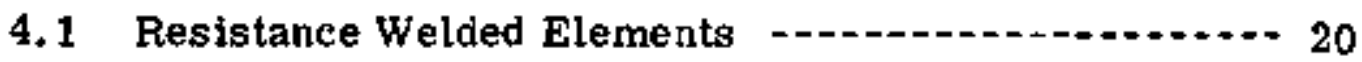

4.2 T.I.G. Welded Elements

4.3 Dynamic Corrosion Test

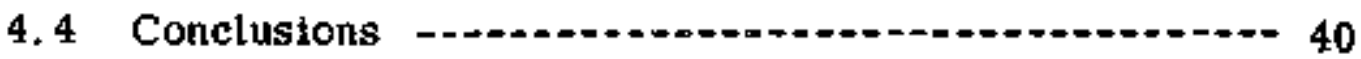

4.5 Recommendations -

APPENDIX I $\quad \ldots$

BIBLIOGRA PHY -

ACKNOWLEDGEMENT - 
WAS INTENTIONALLY

LEET BLANK 


\section{LIST OF ILLUSTRATIONS}

Figure

Title

Page

2.1 Drawing R9-13-1017, Welded Fuel Element

2.2

Segment of Resistance Welded Element

2.3 Segment of TIG Welded Element

3.1 Large Autoclave and Associated Equipment

3.2

High Pressure Corrosion Test Loop

Miniature SM-2 (WTR) Element

4.1

Resistance Welded Element Before Test

4. 2

Resistance Welded Element After $635^{\circ} \mathrm{F}$ Exposure

21 500 Hours

4.3

Upset Zone at Side of Resistance Weld (500X)

4.4

Section of Good TIG Weld After Corrosion (100X)

4.5 Longitudinal Section of a Good TIG Weld (100X)

4. 6

Pre-test Cracking Extending into Fuel Plate (250X)

28

4. 7

Cross Section of Weld which Developed Surface Crack During Exposure (100X)

4. 8

Pitting at Edge of Weld After Huey Test (15X)

4.9

Before (Insert) and After Appearance of Dynamic Test Specimen 


\section{LIST OF ILLUSTRATIONS (CONT'D)}

Figure

$\underline{\text { Title }}$

Page

4. 10

Post-Test Appearance of Welds Showing Slight Etching of Middle Third of Weld (2X)

\section{LIST OF TABLES}

Table

Title

Page

3. 1 Description of Fuel Elements

3. 2

Static Autoclave Water Chemistry

17

3. 3

Loop Test Conditions

18

4. 1

Analyses of Spacing Measurement after Three

37 Thermal Cycles

4. 2

Spectroscopic Analyses of Loop Solids 


\subsection{SUMMARY}

This report covers fuel element corrosion testing performed in conjunction with SM-2 Task 5, Fuel Element Welding Development.

Corrosion tests of tungsten inert gas (TIG) and resistance welded Type 347 ss plate type fuel elements were conducted in degassed neutral water under saturated steam conditions at $635^{\circ} \mathrm{F}$. Both types of welds appeared to have adequate resistance to general surface attack.

In testing of sound TIG welds, cracking was not produced by submerged thermal cycling, $635^{\circ} \mathrm{F}$ aqueous corrosion, boiling $40 \% \mathrm{Mg} \mathrm{Cl}_{2}$ or boiling $65 \%$ nitric acid. No evidence of crevice corrosion was found in TIG welds.

A dynamic corrosion test was performed on a TIG welded element made with annealed fuel plates containing depleted uranium. Adequate corrosion resistance was maintained during a 500-hr exposure to simulated SM-2 coolant. 


\subsection{INTRODUCTION}

This study was undertaken to determine the resistance of welded fuel elements to corrosive attack under SM-2 operating conditions in order that operational corrosion integrity could be established. . Work under Phase 1 consisted of static autoclave testing, to aid in selection of the best welding technique. Phase 2 work, utilizing the selected welding technique, involved several types of corrosion tests including a dynamic test under simulated SM-2 temperature, flow, and water chemistry conditions.

The SM-2 coolant will be high purity deaerated water of nominally neutral $\mathrm{pH}$. Hydrogen will be added primarily to control the dissociation of water under flux (1) as shown by the following equation:

$$
\mathrm{H}_{2} \mathrm{O} \underset{\gamma}{\stackrel{n^{\circ}}{\gamma}} \mathrm{H}_{2}+1 / 2 \mathrm{O}_{2}
$$

Hydrogen also prevents an acid pH occurring in the event that nitrogen (air) is accidentally introduced into the primary system. In the absence of radiation and where oxygen is maintained at low levels, hydrogen probably has no appreciable inhibiting effect on corrosion of stainless steel. (1) Therefore, because of the difficulty in maintaining hydrogen in a static autoclave no hydrogen was added to the water during the corrosion tests described herein.

Coolant flow in the SM-2 varies from element to element. The maximum flow rate was selected for the dynamic study since it is probably the more severe from a corrosion standpoint. (2)

\subsection{CORROSION OF TYPE 347 STAINLESS STEEL}

Type $347 \mathrm{ss}$ is a corrosion resistant alloy (See Appendix I) stabilized with Cb to inhibit sensitization. Stainless steel (Type 347) corrodes uniformly at a maximum rate of $0.4 \mathrm{mils} / \mathrm{yr}$ in high purity water at temperatures up to $600^{\circ} \mathrm{F}$. (3) Slight pitting of Type $347 \mathrm{ss}$ at $650^{\circ} \mathrm{F}$ under dynamic (flowing) conditions is reported. (4) Crevice corrosion is probably not a problem (in non-moving parts) if oxygen. is kept below 0.15 ppm. (5) The effect of nascent oxygen in flux zones is not known. Type 347 ss may be more susceptible to stiress corrosion than type 304 ss. (6) The above statements apply generally to rolled sheet in either the cold-worked or annealed condition. 
The severe local heating of the weld zone may affect the local corrosion resistance. The high residual stresses present due to welding may make the material subject to stress corrosion.

The corrosion study herein described used the above information as a guide in design of tests and in analysis of the test results.

\subsection{WELDING TECHNIQUES}

The technique of welding offers the following advantages over brazing of fuel elements:

1. Lower manufacturing equipment costs.

2. Fewer fabrication steps, also resulting in lower costs.

3. Faster production.

4. Improved tolerances in the finished element.

5. More control during production because each weld is individually done.

6. Dead edge width requirement is reduced,providing better heat and flux distribution.

A preliminary drawing of the SM-2 fuel element design is shown in Fig. 2.1 (Dwg. R9-13-1017). Eighteen fuel plates are joined by welding to two side plates. Two welding techniques were investigated, resistance welding and tungsten inert gas (TIG) welding. Fuel element design differed in certain minor aspects, depending on the intended welding technique.

With the resistance welding process, the side plates were given a series of transverse crimps and the welding took place at the junction of the edges of the fuel plates and the apex of the crimps (Fig. 2.2). The weld itself was generally a small spot with a heat affected area of up to $1 / 8$-in. With the TIG welding process, the side plates were slotted longitudinally. The fuel plate was fitted into the slots and a series of equally spaced welds, formed by fusing thru the side plate at the bottom of of the slots, joined the fuel plates to the side plates (Fig. 2.3). Onehalf inch long welds have been used to date. The heat affected area was as wide as $1 / 8$ in. 
This sideplates used in Phase 1 testing were 0.030 in. thick; those during Phase 2 were 0.040 in. thick. All elements were constructed entirely of solid type 347 ss (except for the dynamic test in which type $347 \mathrm{ss}$ clad fuel: plates contained depleted uranium oxide: dispersion). 


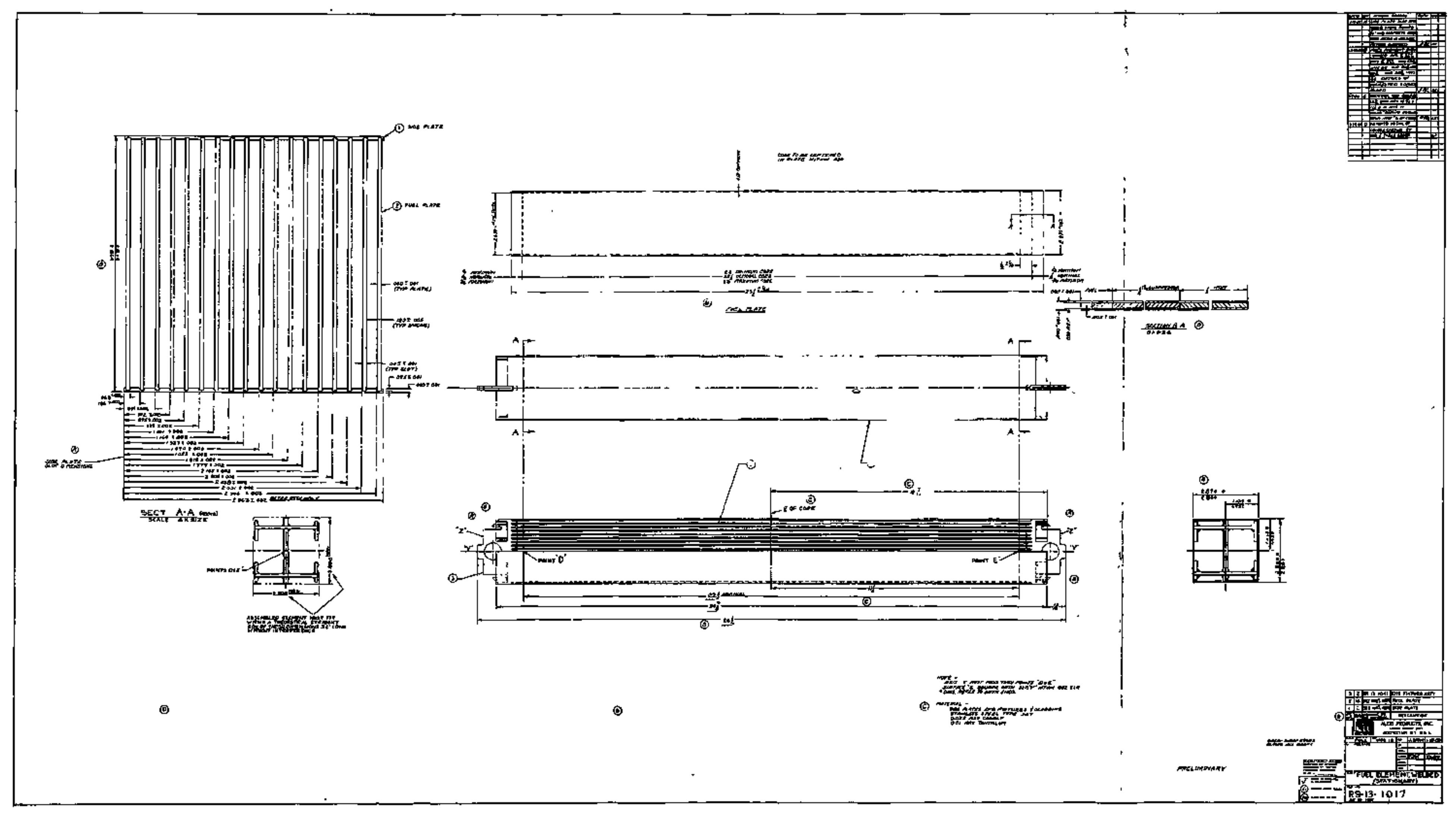

Fig. 2.1 


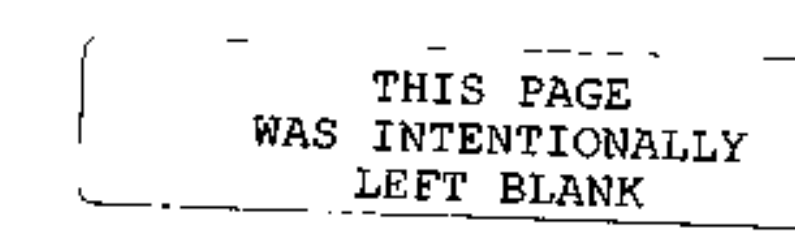




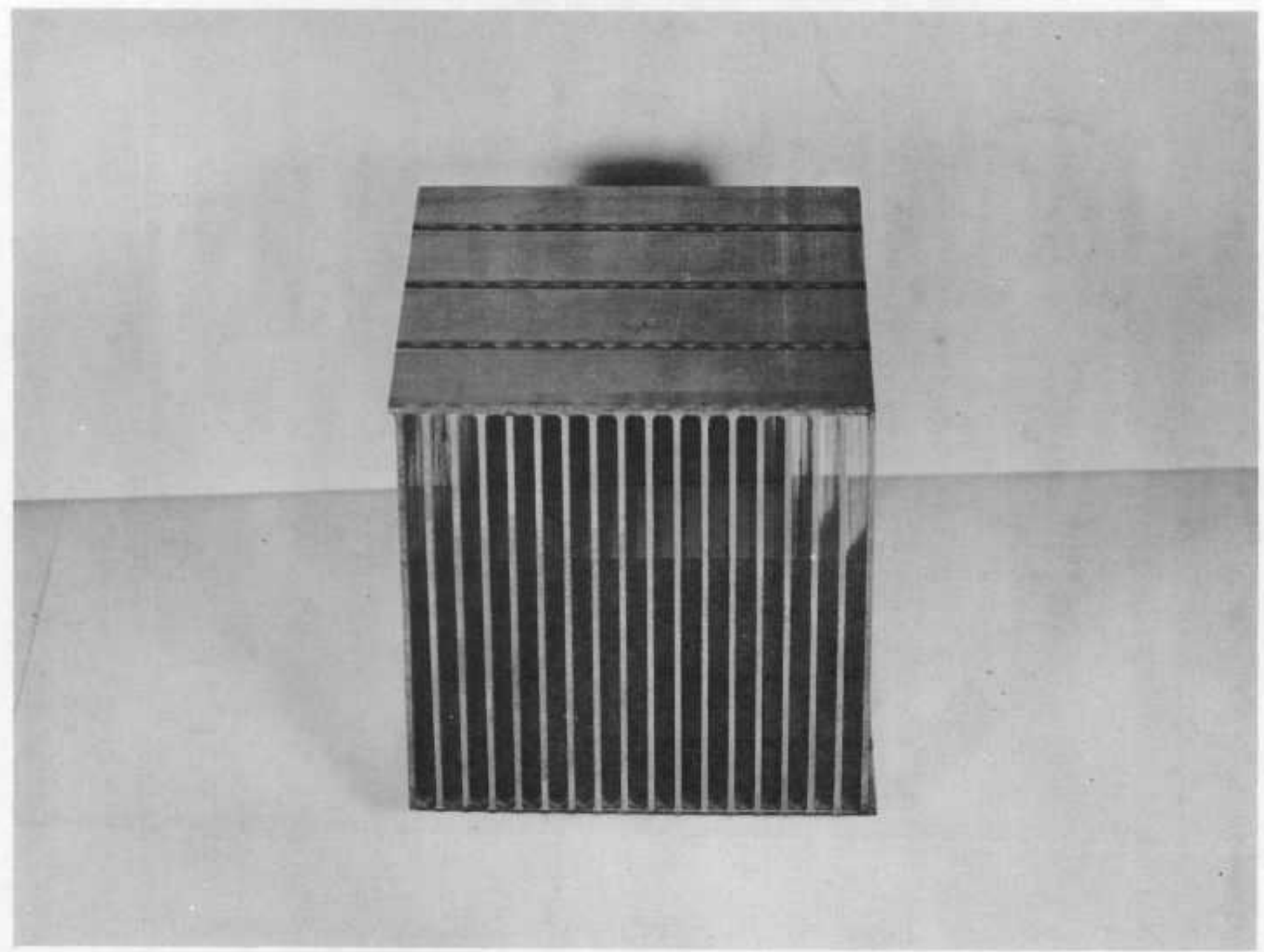

Fig. 2. 2 - Segment of Resistance Welded Element 


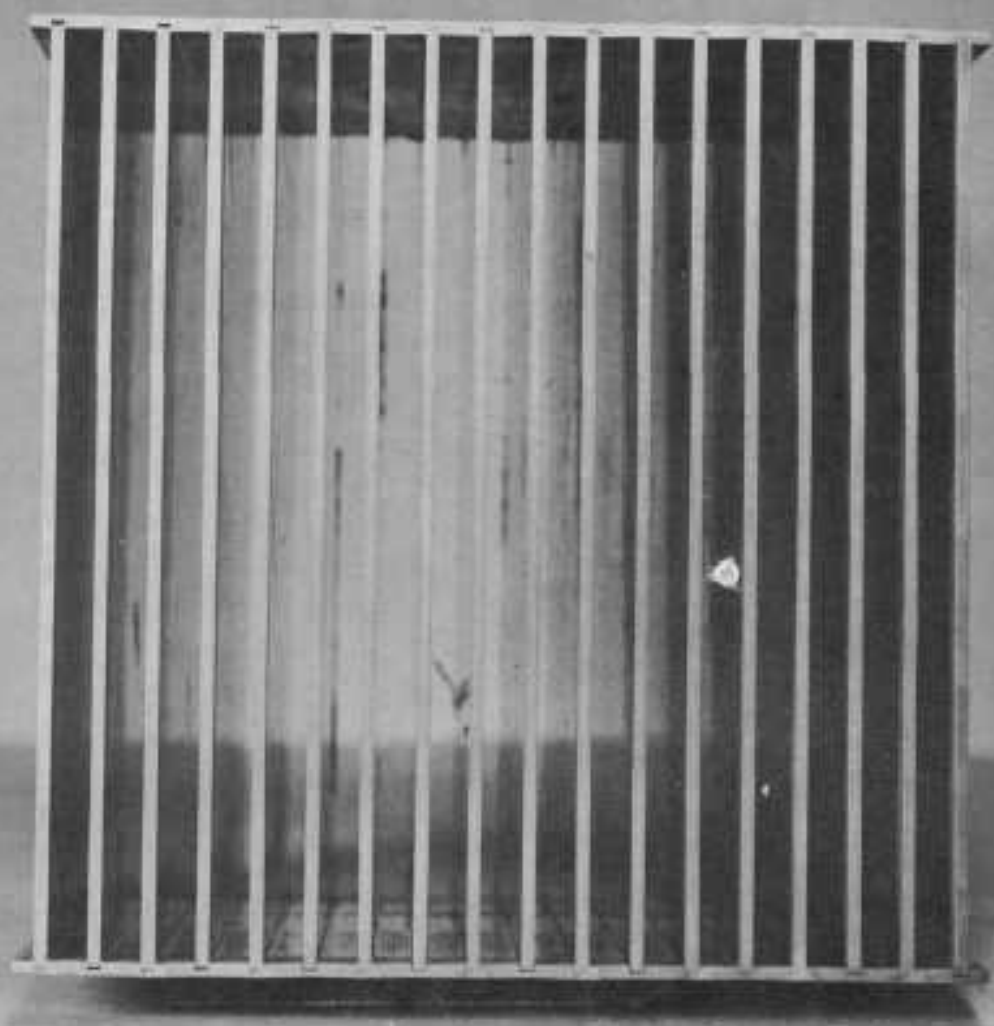

Fig. 2.3 - Segment of T. I. G. Welded Element 


\subsection{EXPERIMENTAL WORK}

Corrosion testing of the welded fuel elements was designed to determine susceptibility to the various types of corrosion discussed in Section 2.1. - Diring.Phase. I, general corrosion integrity of the welds was investigated in static autoclaves. Phase 2 involved more detailed investigations of several types of corrosive effects on the elements welded by the selected technique.

\subsection{TEST EQUIPMENT}

Initial tests were conducted in stainless steel autoclaves equipped with strap-on external heaters. Figure 3.1 is a view of a 5 in. by 40 in. autoclave with its control panel. This autoclave could accommodate a full length element. A temperature gradient was found to exist in this autoclave. The bottom operated approximately $80^{\circ} \mathrm{F}$ cooler than the set polnt while $8 \mathrm{in}$. from the bottom the temperature equalled that of the control point. It is believed that convection currents were adequate to maintain an even temperature except for the cold pocket extending about 8 in. upward from the bottom. A smaller 5 by 12 in, autoclave of similar construction: and with similar auxiliary equipment was also used. No significant thermal gradient existed in this smaller autoclave but only half length elements could be accommodated in it.

A high pressure loop capable of maintaining $550^{\circ} \mathrm{F}$ and 2000 psi was used for the dynamic test (Fig. 3.2). The loop was equipped with a bypass purification system for maintaining water purity. The mixed bed resin also served as a filter for removing suspended crud. The loop water was degassed by boiling before start of testing. It was possible by this method to reduce oxygen to less than 70 parts per billion (ppb). Makeup water was passed through a copper deoxygenating resin. During the actual test, oxygen levels could be held below $5 \mathrm{ppb}$.

The dynamic corrosion test was conducted simultaneously with a rod drop life test. The flow requirements for the two tests differed in that a constant flow was desired in the corrosion test section while the rod drive section required various flows. By suitable manipulation of valves, both flow requirements could be satisfied except for brief fluctuations while adjusting the valves. 


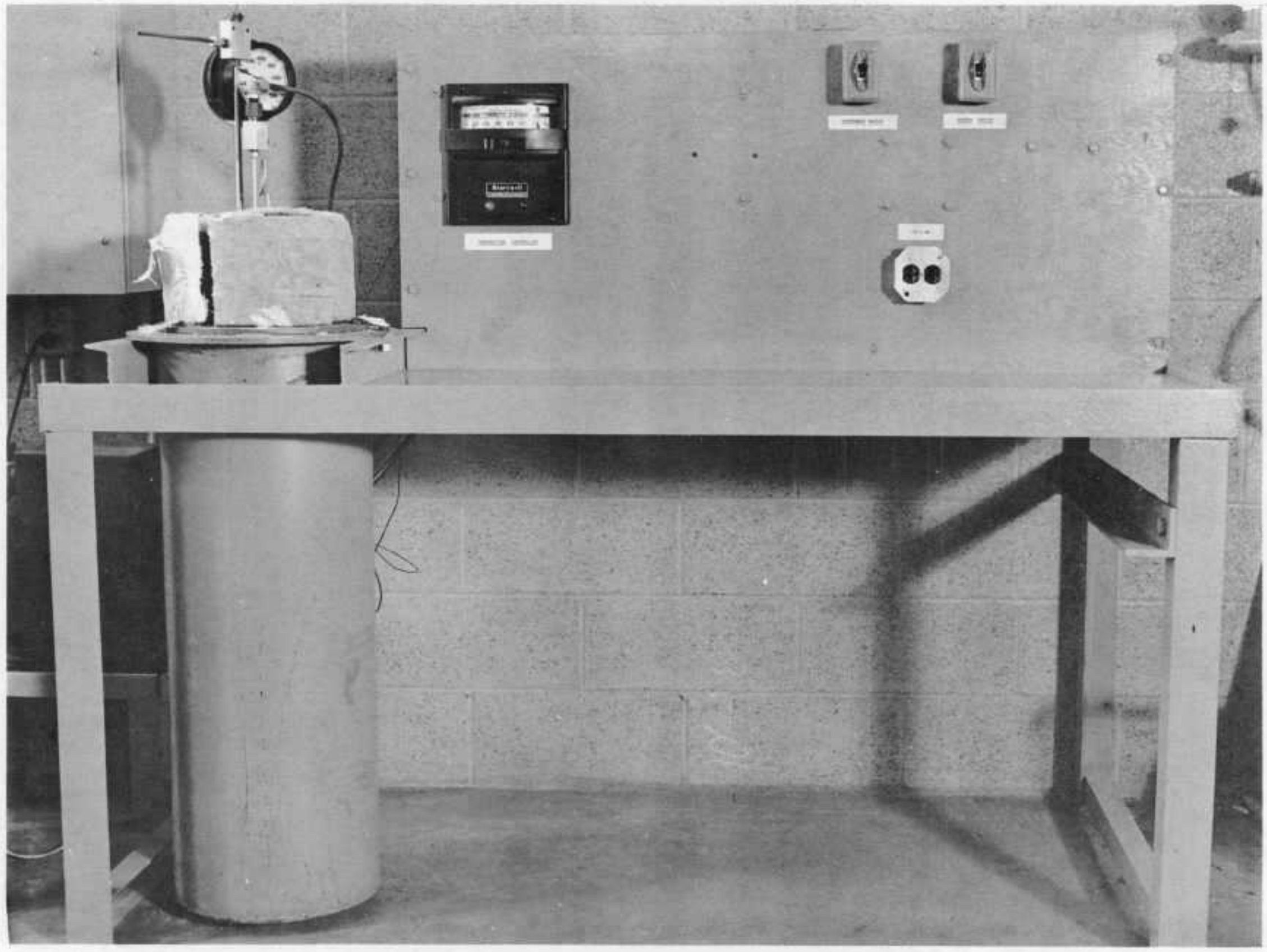




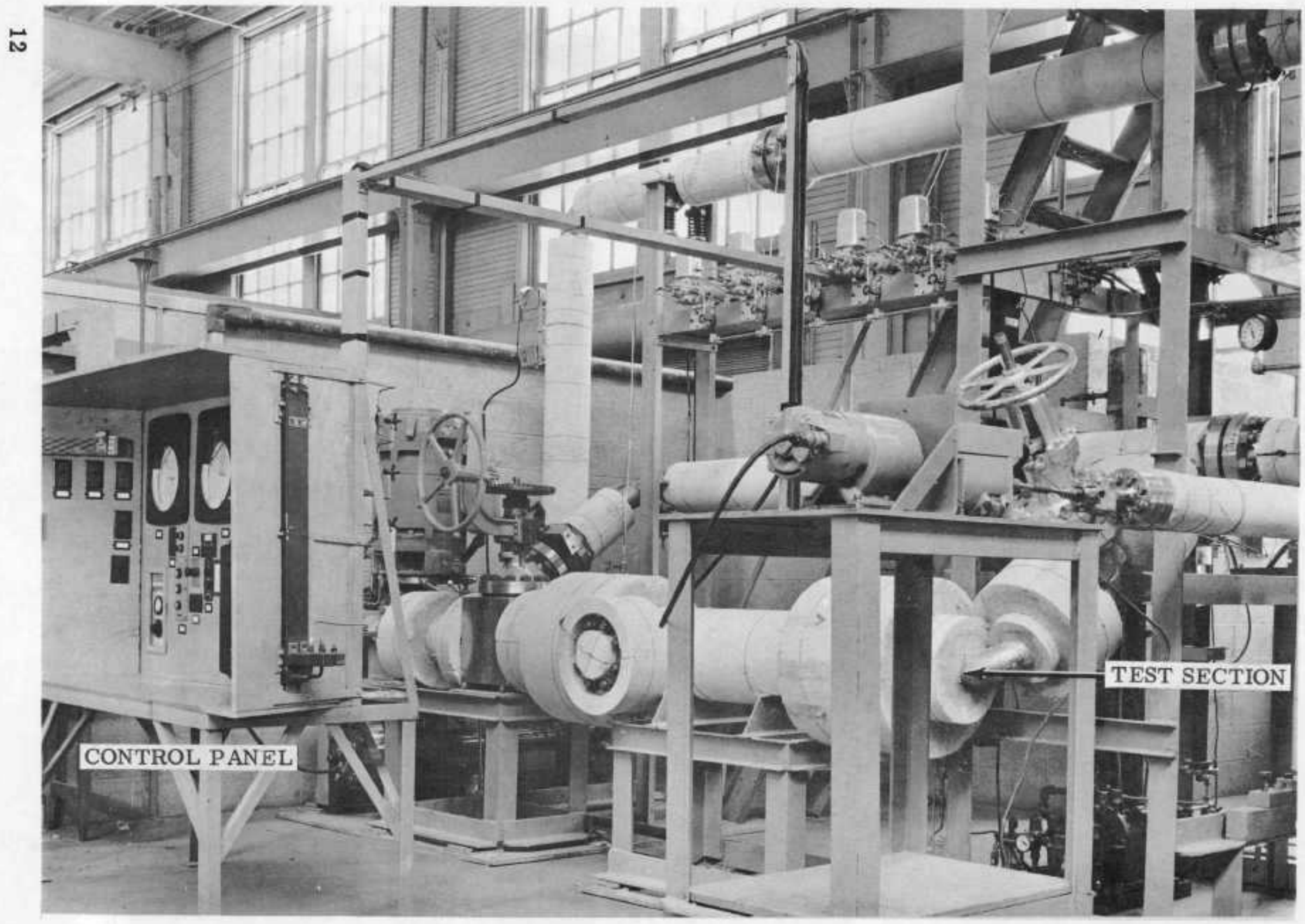

Fig. 3. 2 - High Pressure Corrosion Test Loop 
The desired flow through the test section was set by the maximum fuel element flow of $320 \mathrm{gpm}$ in the SM-2 core. There was $5 \%$ leakage around the corrosion test element. The total flow required through the test section, therefore, was the sum of the 320 gpm internal flow plus the $5 \%$ (16 gpm) external flow, or a total of $336 \mathrm{gpm}$. The flow was measured by pressure drop across the entire test section including the losses due to the specimen mounting brackets and flow directing baffles. The pressure sensing points were located at the inlet and outlet flanges to the section. The flow was calibrated against the main flow orifice meter at $250^{\circ} \mathrm{F}$. The actual test temperature was $550^{\circ} \mathrm{F}$. This temperature difference may have resulted in a slight error in the reported flow.

\subsection{PREPARATION OF FUEL ELEMENTS FOR TEST}

The fuel elements were welded for corrosion testing by either the resistance or TIG technique. Because the welding techniques themselves were continually being improved, the quality of welds varied somewhat from element to element. The later elements were characterized by fewer defective welds. In some cases there was a variation in the welding parameters so that weld quality possibly varied from joint to joint.

The elements were carefully inspected and plate spacings were measured by the Welding Laboratory before receipt by the Corrosion Laboratory. Table 3.1 lists and describes the fuel elements tested. Elements 2, 4, and 8 were tested as welded. The balance were given special treatments or handling.

\section{TABLE 3.1}

\section{DESCRIPTION OF FUEL ELEMENTS}

\begin{tabular}{cll} 
Element No. & Type of Weld Joints & Form in Which Tested \\
\cline { 1 - 2 } Phase 1 & & \\
1 & Resistance Welded & Full Length Element \\
2 & Resistance Welded & Half Length \\
3 & T.I.G. Welded & Full Length \\
4 & T.I.G. Welded & Full Length \\
5 & T.I.G. Welded & Cut in 1 in. Sections
\end{tabular}


Phase 2

6

7

8
Type of Weld Joints

T.1.G. Welded

Miniature SM-2 (see text)

T. 1.G. Welded

(Depleted Plates)

T. I, G. Welded
Form in Which Tested

See Sec, 3,4

Full Fength

Dynamic

Cut in $\mathrm{I}$ in. Sections

Elements 1 and 3 were given chemical cleaning to remove oxide films caused by welding and to determine the effects of such surface tir eatiment on: corrosion. Element 1 was given two descaling treatments. On one end (upper when under test) the weld areas were acid cleaned using a proprietary commercial treatment. On the ather end, the cleaning treatment consisted of a $30-m i n i$ soak in $20 \%$ sodium hydroxide, and $5 \%$ potassium permanganate at $180^{\circ} \mathrm{F}$ followed by a dip in $5 \%$ oxalic acid. The surface was then passivated in nitric acid at $120^{\circ} \mathrm{F}$ for $20 \mathrm{~min}$. Element 3 was also chemically cleaned over two weld zones on one end (upper end when in autoclave). This cleaning consisted of a $30 \mathrm{~min}$ soak at $180^{\circ} \mathrm{F}$ in a solution of $10 \%$ sodlum hydroxide and $5 \%$ potassium permanganate. This was followed by a dip in $5 \%$ oxalic acid, in turn followed by water and acetone rinsing.

Element 6 (Fig. 3. 3) was a small version of the SM-2 fuel element and was the pilot model of an active element designed for in-pile studies of burnup, etc. It was cut into two parts for corrosion testing. It had only one defect as shown by dye penetrant.

Element 7 was fabricated from annealed depleted fuel plates. The width of these plates (2.664 in.) did not correspond to SM-2 standard size. This necessitated shimming of the assembly in the welding fixture and resulted in scratching of the outer fuel plates. Also because of the unusual shimming, the first and last rows of welds were not representative of good welding technique.

\subsection{WATER CHMISTRY}

One of the main characteristics of pressurized water reactor coolant is the extreme purity requirement. For this reason the fuel elements were carefully cleaned just before inserting in test. The procedure used is given below. Slight modifications were made depending on the extent and nature of the fuel element contamination. 


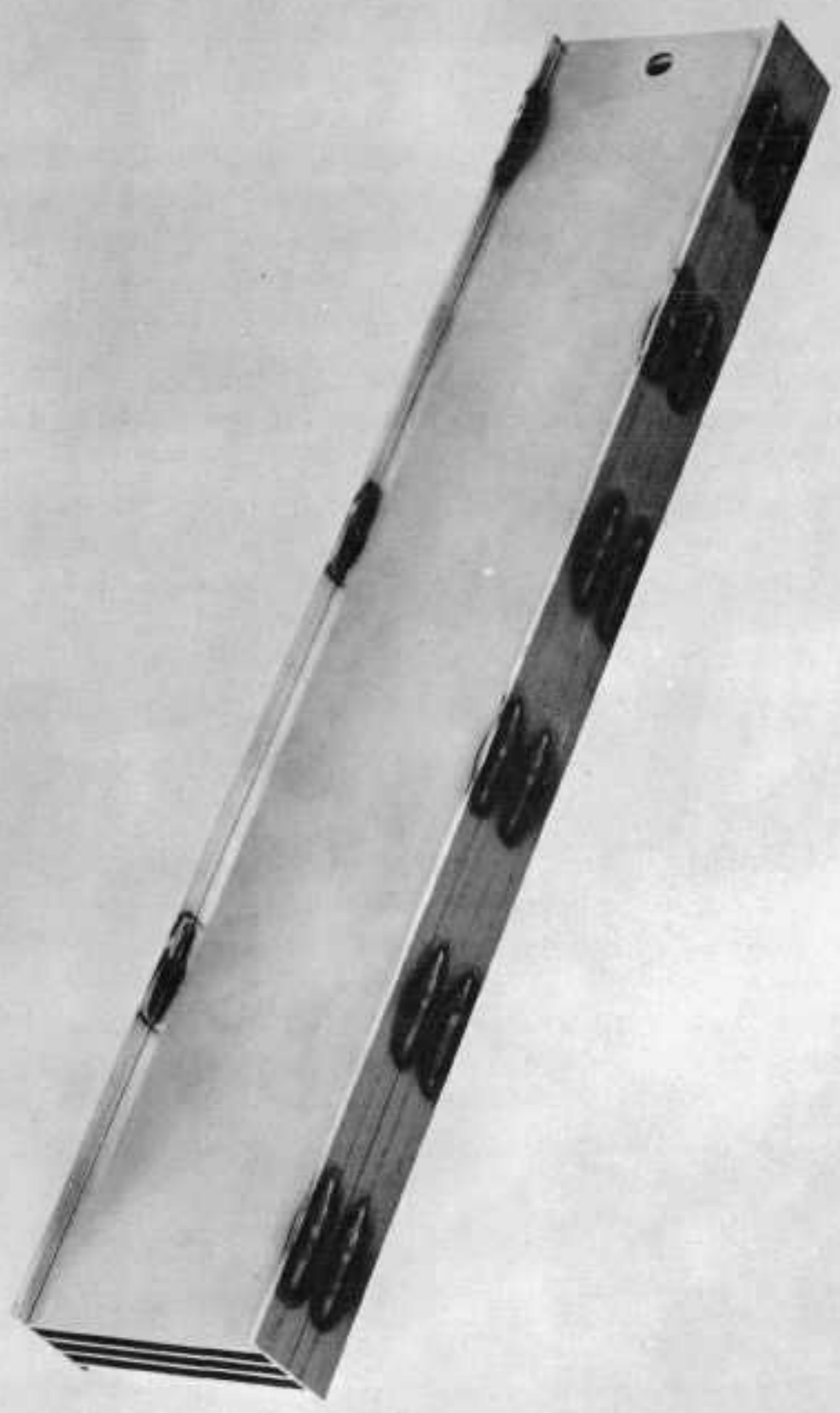

Fig. 3. 3 - Miniature SM-2 (WTR) Element 
THIS PAGE

WAS INTENTIONALLY

LEFT BLANK 


$\begin{array}{ll}\text { First rinse } & 1 \% \text { Sparkleen in } 180^{\circ} \mathrm{F} \text { water } \\ \text { Second rinse } & \text { Demineralized water } \\ \text { Third rinse } & \text { Acetone } \\ \text { Fourth rinse } & \text { Carbon fetrachloride } \\ \text { Fifth rinse } & \text { Acetone } \\ \text { Sixth rinse } & \text { Demineralized water }\end{array}$

After cleansing, the test elements were handled only with clean cotton gloves or clean shop towels.

Before each test the autoclave was washed out with demineralized water and wiped with paper toweling to remove loose crud. The fuel element was set on the bottom of the autoclave and sufficient water charged to the autoclave to insure that the element remained submerged at all times. The test water was demineralized by passage through a mixed bed ion exchange resin. In all cases the water purity as charged was above 0.7 megohm-cm resistivity, and had a pH of 6.5 to 7.5. Table 3.2 shows the chemistry of the static autoclave water before and after testing. After adding water the autoclave was closed and evacuated for $\mathbf{3 0} \mathrm{min}$ to remove air. (oxygen) before sealing. The degassing was completed by venting briefly $(30 \mathrm{sec})$ at $250^{\circ} \mathrm{F}$. The temperature of $635^{\circ} \mathrm{F}$ was then obtained as rapidly as possible and held for duration of test.

TABLE 3.2

\section{STATIC AUTOCLAVE WATER CHEMISTRY}

\begin{tabular}{cc}
$\begin{array}{cc}\text { Test } \\
\text { No. }\end{array}$ & $\begin{array}{c}\text { Test Duration, } \\
\text { Hours }\end{array}$ \\
\cline { 2 - 2 } 1 & \multicolumn{2}{c}{497} \\
$2^{*}$ & 549 \\
3 & 501 \\
4 & 484 \\
$5 * *$ & 1,336 (a) \\
& (b) \\
6 & 1,386
\end{tabular}

Before Test

Resistivity

ohm-cm pH Oxygen

800,000

6. 8 degassed

700,000

900,000

$1,400,000$

$1,500,000$

$<1,000,000$

$1,000,000$
- degassed

6.5 degassed

7.3 degassed

degassed not degassed

same as test 5
After Test Resistivity

\begin{tabular}{cccc} 
ohm -cm & & pH & Cl \\
\cline { 1 - 1 } & & 8.2 & - \\
- & 8.4 & - \\
80,000 & 7.4 & - \\
85,000 & 7.6 & - \\
- & & - & - \\
105,000 & 7.8 & 0.2 \\
- & 7.2 & 0.5
\end{tabular}


Slightly different chemistry conditions prevailed when testing elements 5 and 6 . As previously mentioned these elements were sectioned before testing. The individual sections were placed in the $1 \mathrm{gal}$ autoclave with the fuel plates vertical and the welded edges downward. The autoclave was charged with water as outlined above. During the first exposure period the autoclave operated with degassed water. During the final $500 \mathrm{hr}^{*}$ the autoclave was not degassed and operated with the water saturated with air plus the air present in the overhead space. The high oxygen level was used in an effort to determine if stress corrosion cracking could occur. The dissolved oxygen concentration was estimated at about $270 \mathrm{ppm}$ at start of this test. The concentration would decrease during the course of the test as oxygen was consumed by the corrosion reaction.

TABLE 3.3

LOOP TEST CONDITIONS

$\begin{array}{lrrr} & \text { Nominal } & \text { Low } & \text { High } \\ \text { Pressure (psi) } & 1900 & - & - \\ \begin{array}{l}\text { Flow (gpm) Total } \\ \text { Test Section }\end{array} & 380 & 344 & 407 \\ \text { Resistivity (ohm-cm) } & 500,000 & 380,000^{* *} & 3,000,000 \\ \text { Oxygen (ppb) } & 10 & 0 & 10^{* * *} \\ \text { pH } & 7 & 6.6 & 7.6 \\ \left.\text { Temperature ( }{ }^{\circ} \mathrm{F}\right) & 550 & 535 & \\ \text { Duration (hr) } & 486 & - & \end{array}$

The dynamic loop was carefully washed with commercial "All" detergent solution before assembly. After rinsing and inserting of the depleted test element, the loop was sealed and filled with demineralized water.

The loop water was degassed by venting the loop from the highest point for $15 \mathrm{~min}$. Alternating with the venting was a 5-min period during which the pump and loop heaters were turned on. This cycle was repeated until oxygen concentration was less than $0.7 \mathrm{ppm}$. A temperature between 230 and $250^{\circ} \mathrm{F}$ was maintained during degassing of the loop. Loop water conditions are shown in Table 3.3

* Test 5, final $493 \mathrm{hr}$; test 6 , final $500 \mathrm{hr}$.

** Total time below $500,000 \mathrm{ohm}-\mathrm{cm}$ was less than $2 \mathrm{hr}$.

*** One recorded reading of 25 is believed to be in error. 


\subsection{TEST PROCEDURES}

Channel spacing was measured prior to each test to insure that the elements were within specifications. Close visual inspection of all welds was also made. The specimens were then exposed in the static autoclave for $500 \mathrm{hr}$ at $635^{\circ} \mathrm{F}$. The exposure was timed from the completion of degassing to heater shutoff. After the 1 month exposures, elements were usually examined to determine the general resistance to corrosion. Weld areas were examined for local attack, pitting or cracking. Metallographic specimens were prepared of questionable welds and examined for cracking, knife line attack, crevice corrosion etc. Certain welds, containing defects in the form of small cracks associated with weld craters, were checked for propagation of cracks (Tests 5 and 6 ).

Following selection of the.T. I.G. welding technique for use with $0.040 \mathrm{in}$. side plates, more detailed studies were conducted. A submerged thermal cycling test was carried out on the half length (element 6) specimen previously described. Six cycles to $635^{\circ} \mathrm{F}$ were made with a heating and cooling rate of $200^{\circ} \mathrm{F} / \mathrm{hr}$ and $100^{\circ} \mathrm{F} / \mathrm{hr}$ respectively. This specimen was visually examined for surface cracking then etched* to remove surface scale and checked for surface cracks both microscopically $(45 \mathrm{X})$ and by flourescent dye penetration. .

To determine the resistance of the welds to stress corrosion cracking and intergranular attack, element. 7 was cut into five weld segments. One of these was immersed in boiling $40 \% \mathrm{MgCl}_{2}{ }^{(7)}$ for two $72-\mathrm{hr}$ periods. A second was boiled in $65 \%$ nitric acid, (the Huey test); (8)

The dynamic test element was measured for plate spacing before testing and immediately after conclusion of the test. It was inspected visually and under 30X magnification. Since the element contained depleted uranium, it was sent to an outside laboratory for metallographic sectioning. Twentyfive weld sections of selected welds were taken both longitudinally and transversely. The sections were viewed at magnifications up to $500 \mathrm{x}$.

* Etch was $20 \% \mathrm{HNO}_{3}-5 \% \mathrm{HF}$ for 2 minutes at $180^{\circ} \mathrm{F}$ 


\section{0 TEST RESULTS AND CONCLUSIONS}

The elements tested during Phase 1 of this study were welded during various stages of the development of welding techniques. Because the welding techniques had not yet been optimized, some welds were not of satisfactory quality. Some resistance welded joints exhibited lack of bonding while other welds exhiblted overheating and excessive amount of extruded metal. Similarly, cracking defects existed in some earlier TIG welds. The elements welded by the TIG technique with 0.040 -in. side plates have been practically free of weld defects (Phase 2 elements).

In early development elements where defects were common, it was difficult to determine whether a post-test defect was caused by corrosion or had been present in the weld prior to testing. Every effort was made to take this into account when evaluating the test results.

\section{1 RESISTANCE WELDED ELEMENTS}

During the subject study, resistance welding development was discontinued (because of inability to produce cons istent welds of satisfactory quality) in favor of the tungsten inert gas technique. Figures 4.1 and 4.2 show respectively a typical resistance weld section as it appeared before corrosion and a similar weld after corrosive exposure for 1 month.

Metallographic examination of the surface of the corroded specimens showed only the normal slight general surface attack expected on type $347 \mathrm{ss}$ under the test conditions. Figure 4.3 shows a close-up of the upset zone of a resis tance weld. The cracking illustrated could be a result of corrosion, interdendritic cracking during welding, or the latter followed by crack extension by corrosion. Because the development of the resistance welding technique was terminated, corrosion studies were not continued to a point where more definite conclusions could be drawn. The major accomplishment of this part of the corrosion study was determination of possible problem areas. if resistance welding should be reconsidered in the future.

\section{2 TIG WELDED ELEMENTS}

\subsubsection{Phase 1 Studies}

Because there was little difference between results on the first two TIG welded elements (\#3 and \#4) exposed in Phase 1 testing, the results will be discussed together. 


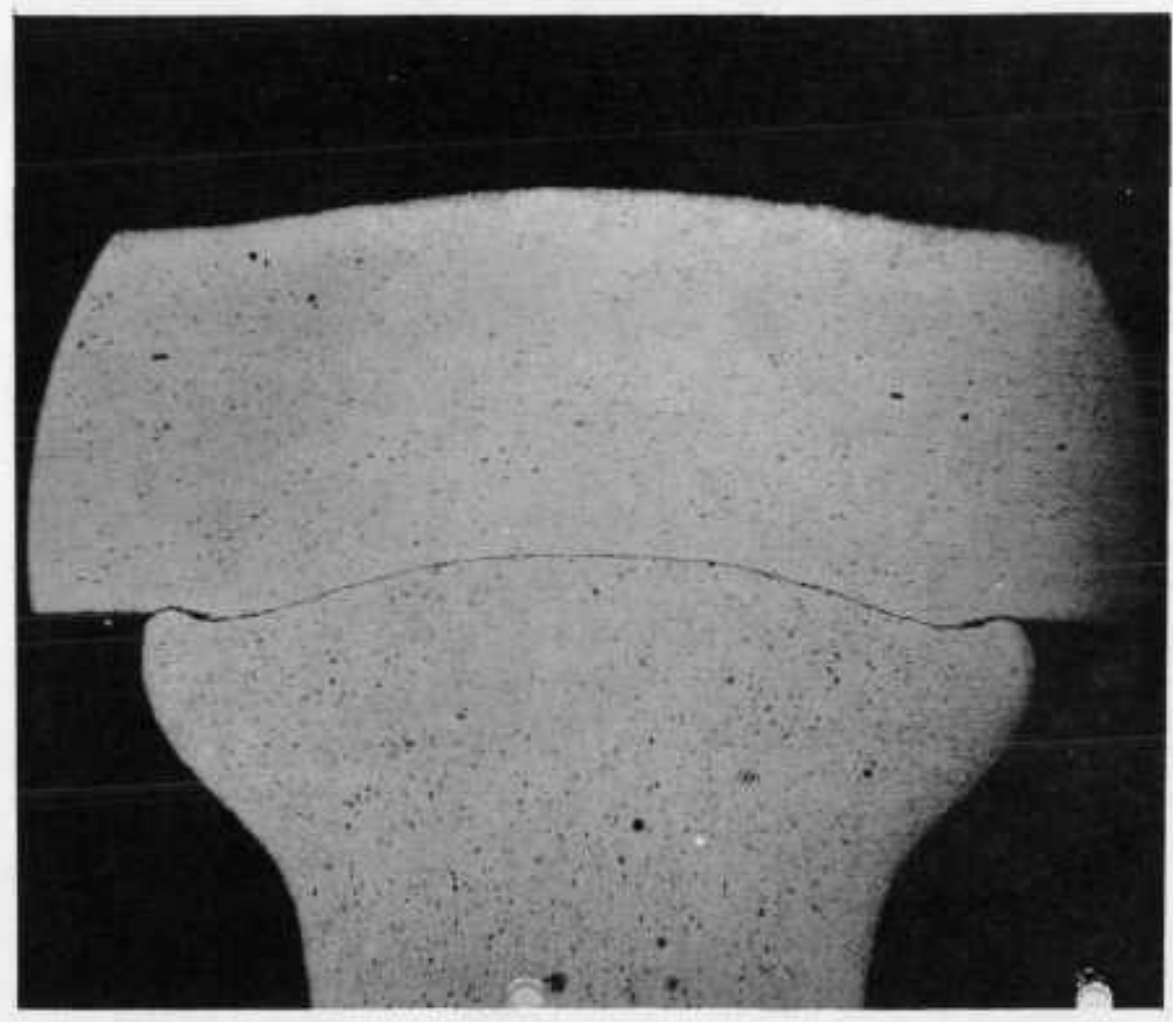

Fig. 4.2 - Resistance Welded Element after $635^{\circ}$ F Exposure for $500 \mathrm{Hrs}$.

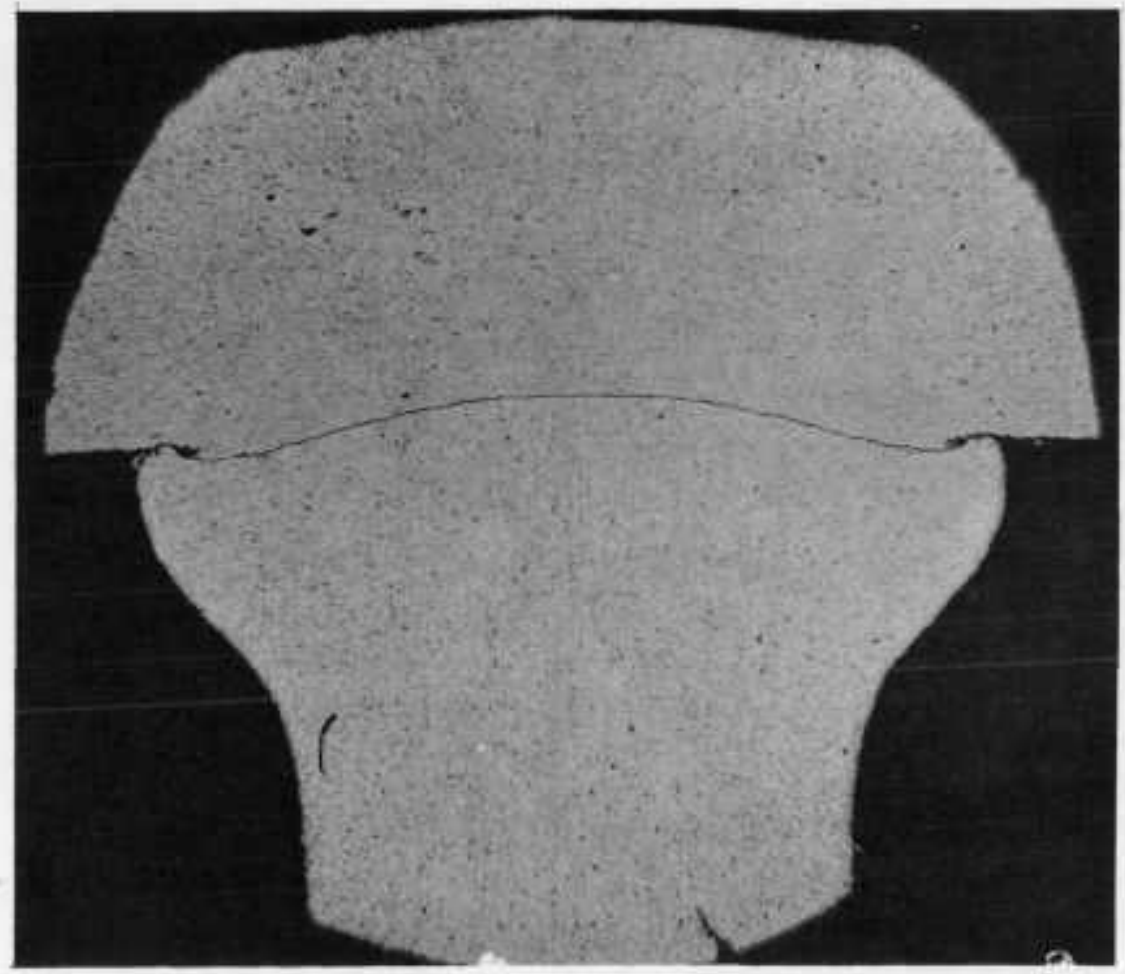

Fig. 4.1 - Resistance Welded Element before Corrosion 
THIS PAGE

WAS INTENTIONALLY

LEET BLANK 


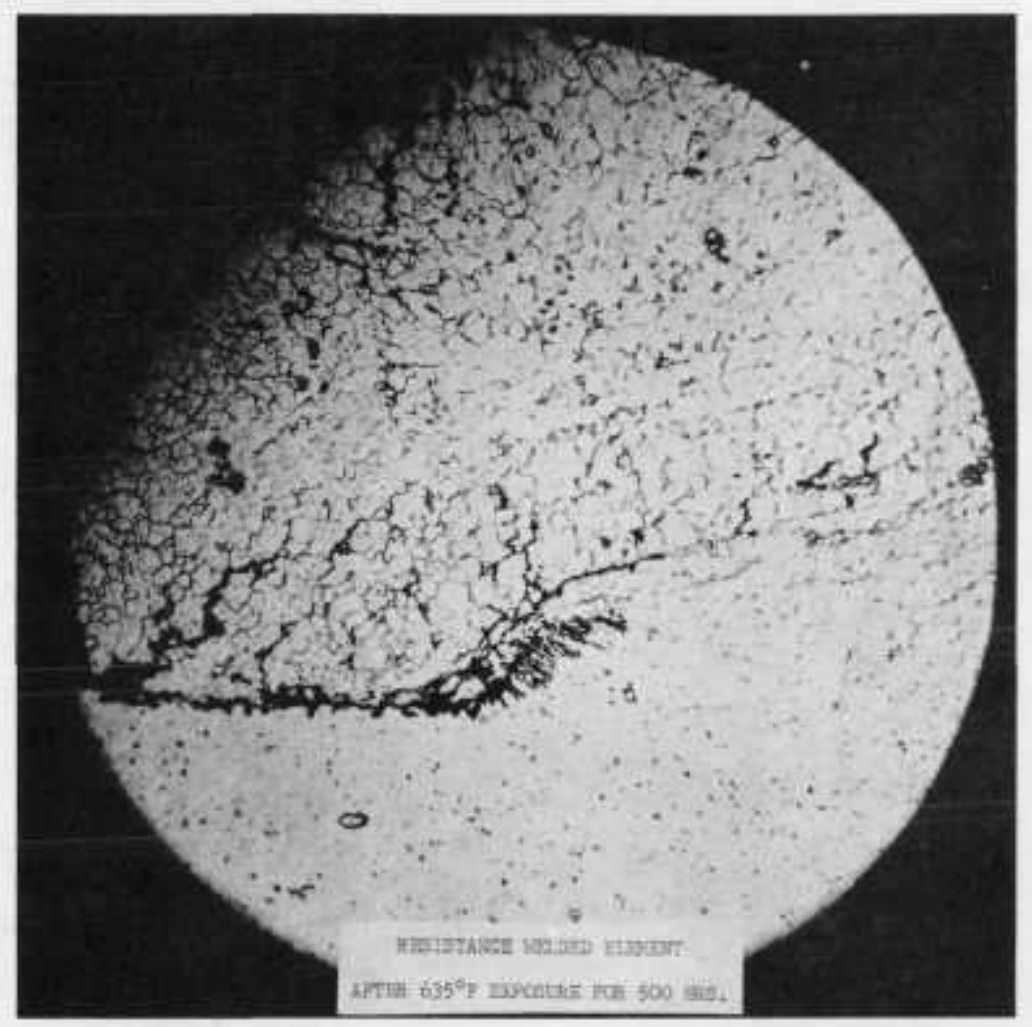

Fig. 4. 3 - Upset Zone at Side of Resistance Weld (500X)

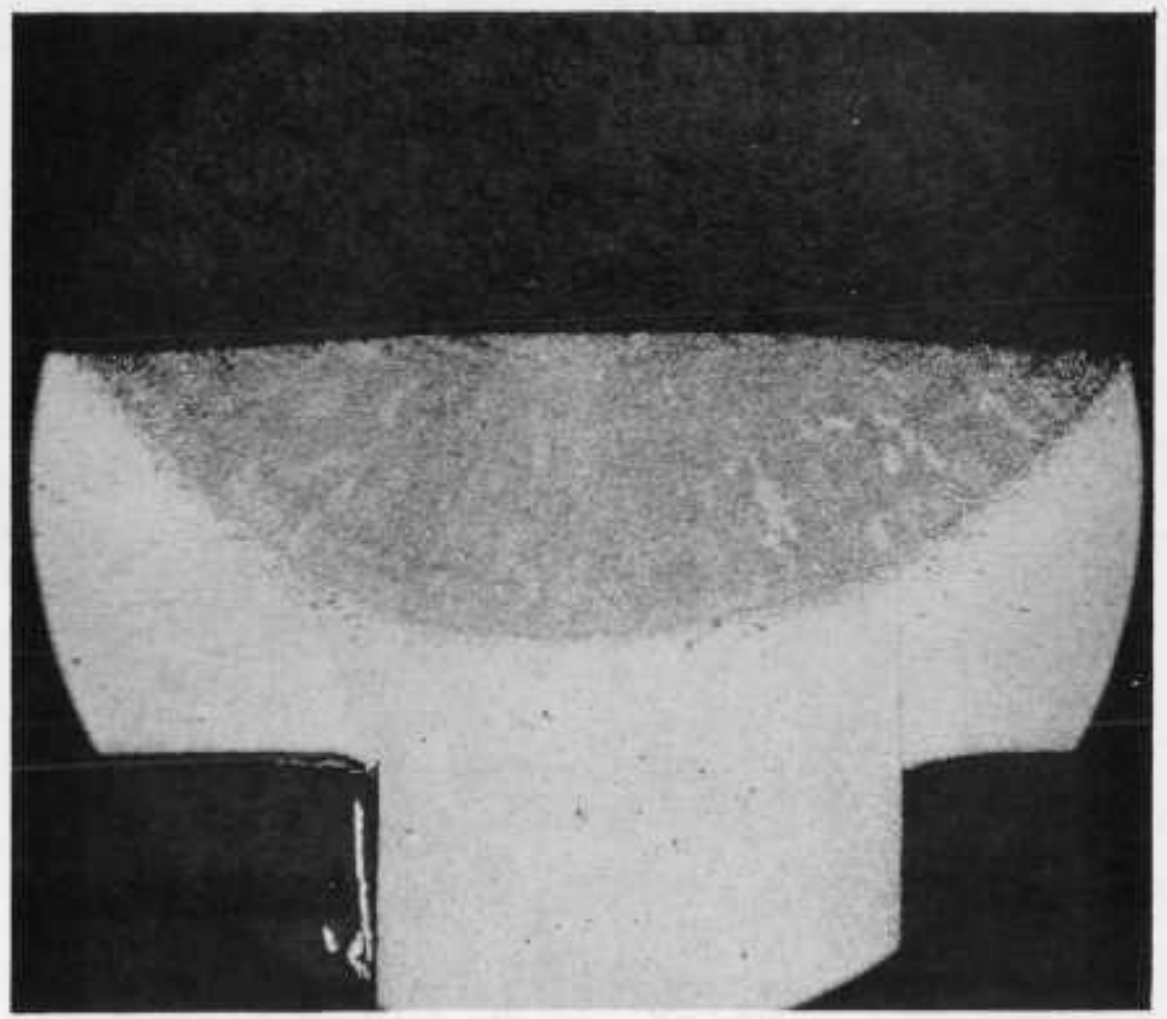

Fig. 4. 4 - Section of Good T. I. G. Weld after Corrosion (100X) 
THIS PAGE

WAS INTENTIONALLY

LEFT BLANK 
Figure 4.4 shows a cross section of a typical good weld after exposure. Only insignificant general surface corrosion is visible and there is no specific attack on the weld surface. Figure 4.5 is a cross section along the length of a weld showing essentially the same good integrity as the transverse view.

Cracking, if found in early welds, was always associated with weld cratering. In some few instances, cracking extended from the crater area at the trailing end of the weld into the fuel plate-side plate fusion as shown in Fig. 4.6. The weld shown in Fig. 4.6 was in an element not exposed to corrosion testing.

Cracking of this type is of interest because propagation into the dead edge of the fuel plate is conceivable. Welds in which propagation might have occurred were found in elements 3 and 4. A more intensive study was therefore undertaken to determine if propagation of cracks could occur in welds in which crater cracks existed.

Elements 5 and 6 were utilized in this test for crack propagation. The behavior of an element with nume rous defects (\#5) was compared with that of an element with no defects (\#6) exposed under similar corrosive exposure. In addition a portion of each element was retained for comparison of before and after appearance.

In element 5, 21 of 27 welds placed in test had cracks prior to testing. Following exposure, cracks were found on four of the six original noncracked welds (based on dye penetrant examination) by examination at 25 diameters magnification. Figure 4.7 shows a cross section of one of the welds which had no visible externat cracking before testing. The area shown in Fig. 4.7 represents the trailing end of the weld in which fusion of the side plate to the fuel plate is not expected. It is probable that in each of the four cases a crack was present in the body of the weld on the fuel plate side before testing. It is not known whether their detection after corrosion is due to improved sensitivity of crack detection or to crack propagation by mechanical causes or stress corrosion.

Element 6 showed no cracks of any kind after exposure. It is concluded therefore, based on the studies to date, that occurrence of cracks in properly welded elements is not expected. Occasional defects not detected by inspection would not be expected to propagate or to cause deterioration of welds to a point which could affect operation of the core. In addition, continued development of welding techniques has improved the quality of welds to the point where no weld cracks are expected. 


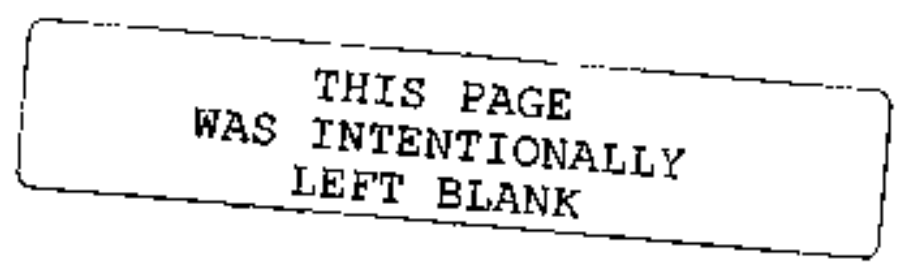




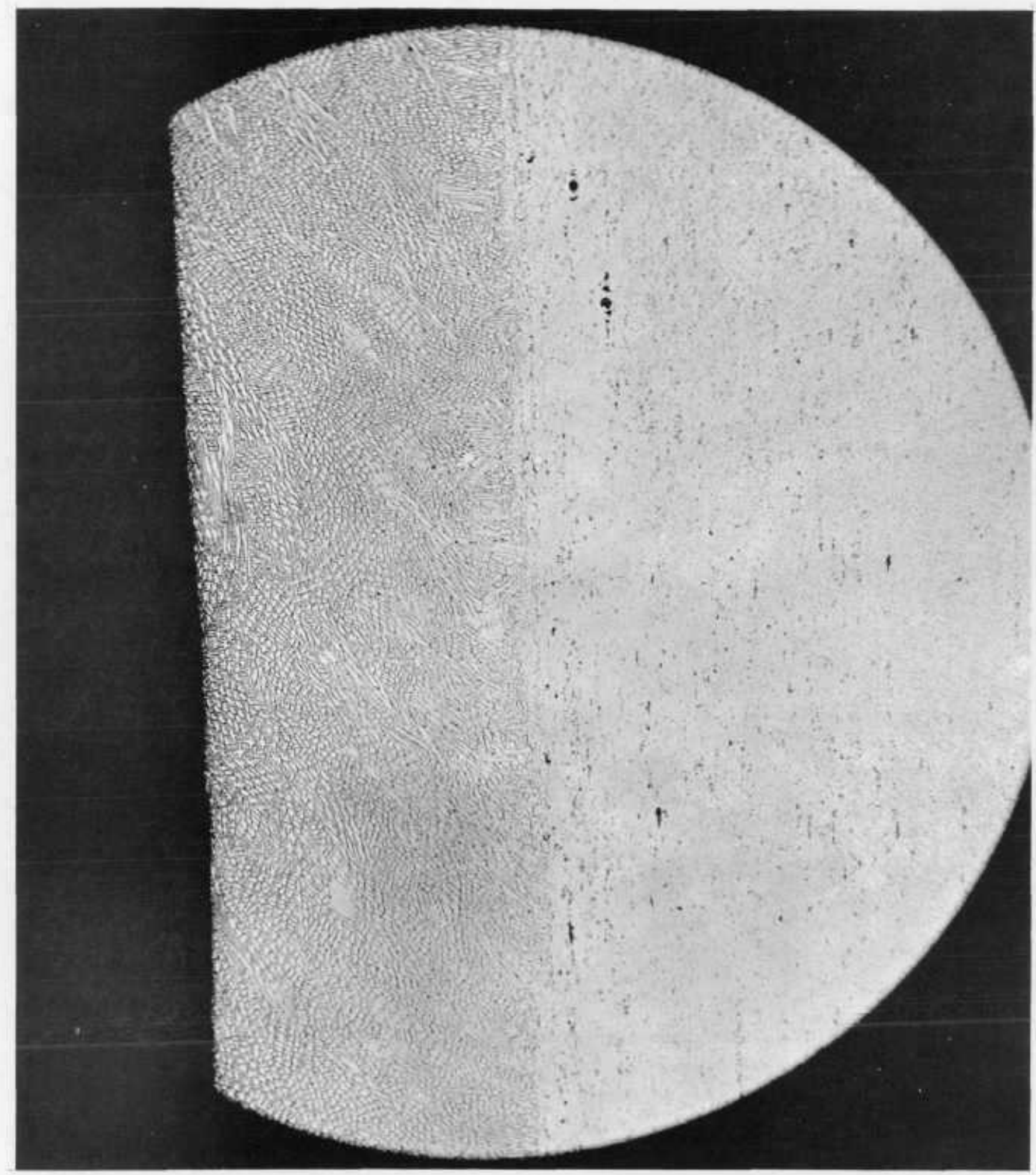

Fig. 4. 5 - Longitudinal Section of a Good T. I. G. Weld after Corrosion (100X) 


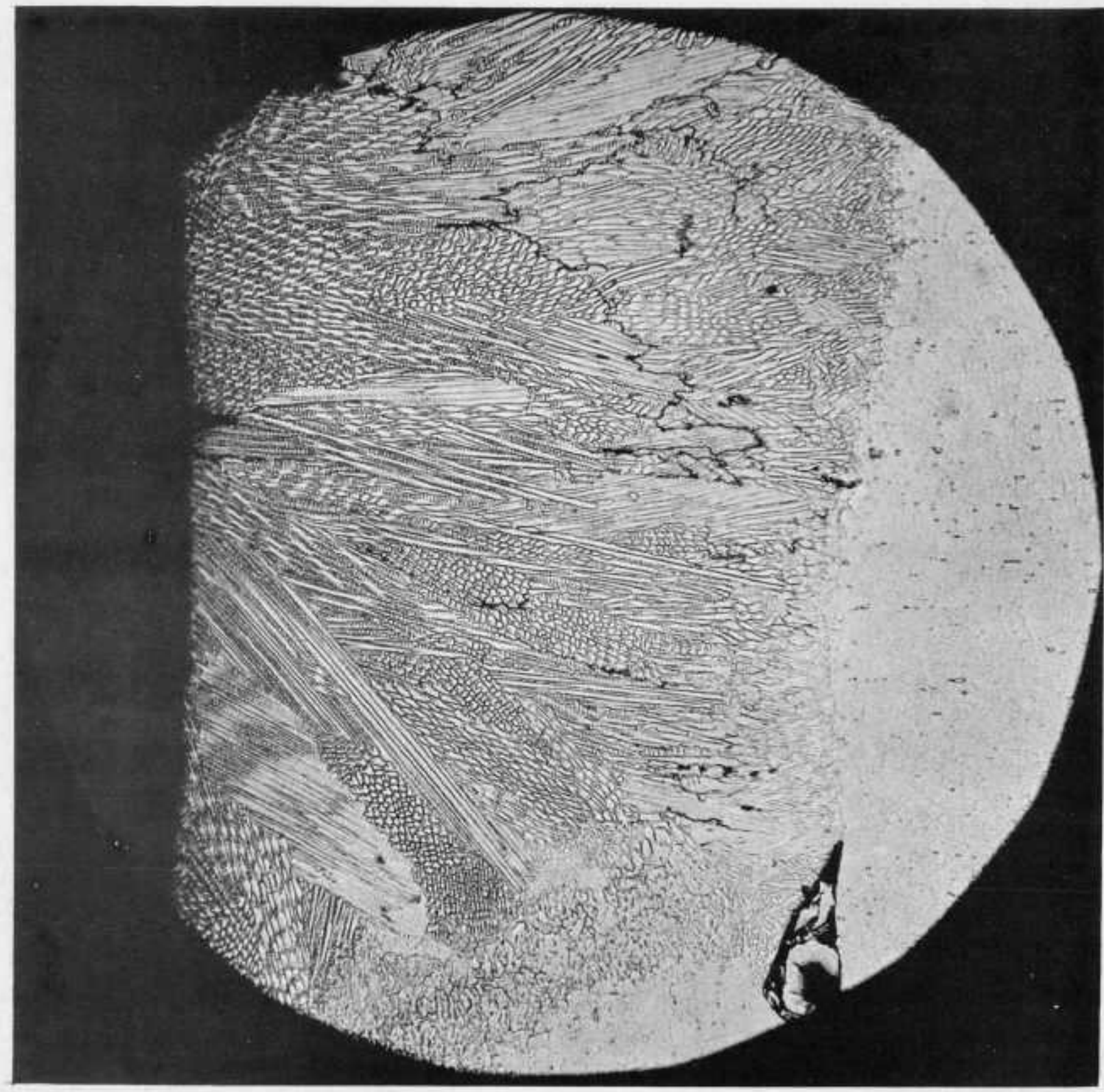

Fig. 4. 6 - Pre-Test Cracking Extending Within 0. 002 Inch of Fuel Plate (250X) 


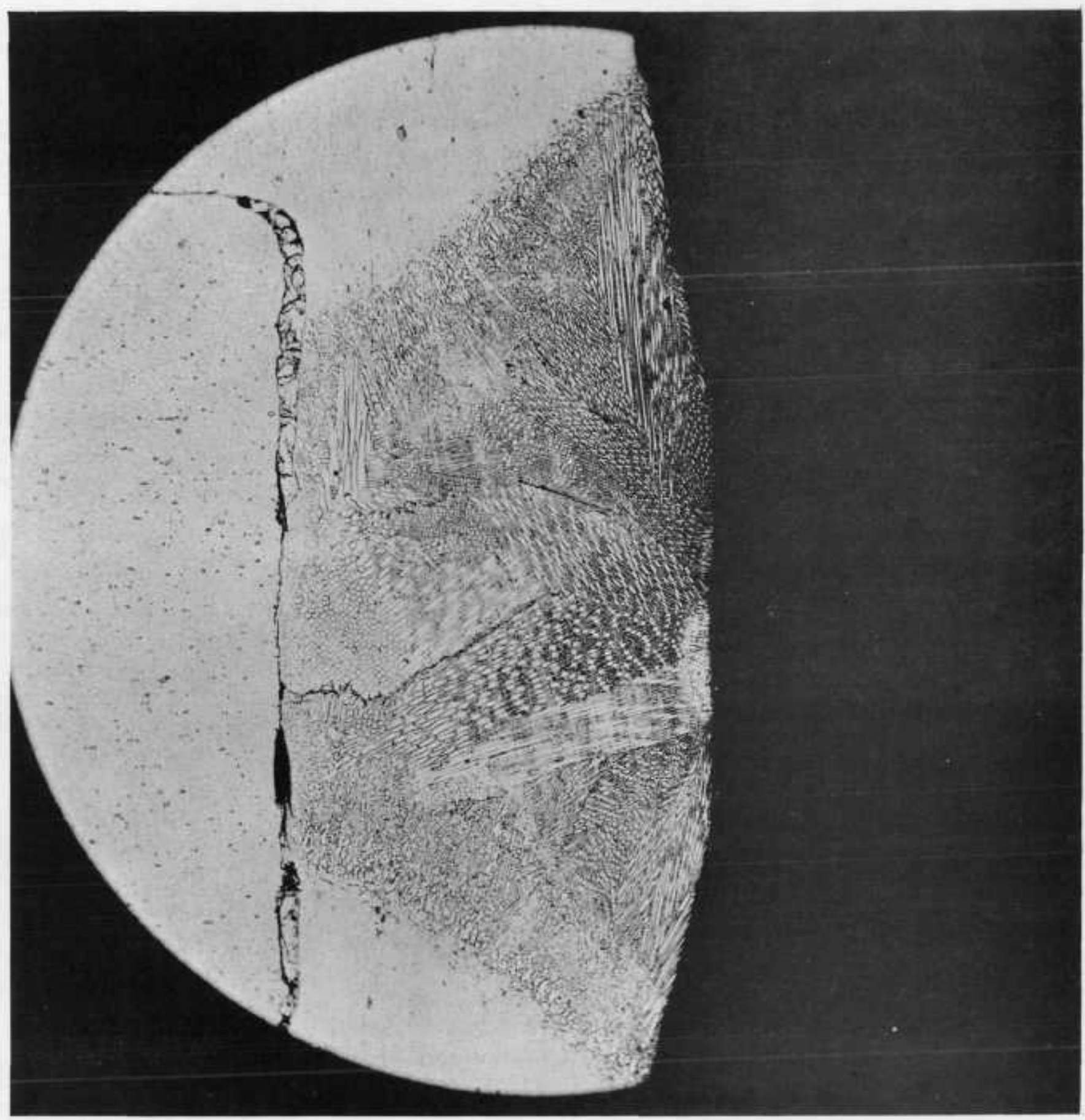

Fig. 4. 7 - Cross Section of Weld Which Developed Surface Crack Only after Exposure (100X) 
THIS PAGE

WAS INTENTIONALLY LEET BLANK 
The axidizing conditions of the test (element.6) did produce slight pitting at the edges of the heat affected zone around the welds. Maximum pit depth was measured as $0.0075 \mathrm{in}$., with an average pit depth of about $0.0035 \mathrm{in}$. In view of the rather severe conditions of the test,this pitting is not considered significant. If necessary in the future to make significant changes in welding conditions, these areas should be re-examined.

\section{2.2 Phase 2 Studies}

The several miscellaneous cracking studies (elements 6 and, 8 ) did not produce evidence of cracking, either by submerged thermal cycling, stress corrosion or by boiling in $65 \%$ nitric acid. Figure 4.8 shows the surface of a portion of a five weld segment after two consecutive 72-hr exposures to fresh $65 \%$ nitric acid. Some pitting attack was observed in the weld zone boundary discussed above. Inasmuch as exposure to degassed water does not produce this type of attack, it is believed of no serious consequence.

\subsection{DYNAMIC CORROSION TEST}

Figure 4. 9 shows the dynamic test specimen before and after the test. After test the element had a slight blue tarnish but showed no other evidence of general corrosive attack.

Measurements of plate spacing changes resulting from the test revealed an average decrease of about 0.00054 in. Table 4.1 shows a comparison between the plate spacing change during the dynamic test (element $D$ ) and that observed during thermal cycling in a dry air atmosphere. The change is roughly comparable to that due to thermal cycling.

Examination of the weld areas at $30 \mathrm{X}$ magnification showed good corrosion resistance (Fig. 4.10). The middle third of the welds had a slight etching, sufficient to show some dendritic pattern. Some indication appeared of erosion of deeply cupped welds in the form of slight scouring at the downstream end of the depression.

Only one definite defect due to corrosion was found, a deep pit roughly in the center of weld 10-3. This surface pit unfortunately was lost in polishing the mounted specimen and no information was gained as to contributing causes. Otherwise the metallographic specimens showed no significant corrosion effects.

At conclusion of the test a large sample of water was drawn and analyzed for total solids. The solids concentration in the coolant was $5 \mathrm{ppm}$. An approximate solids analysis is shown in Table 4.2. 


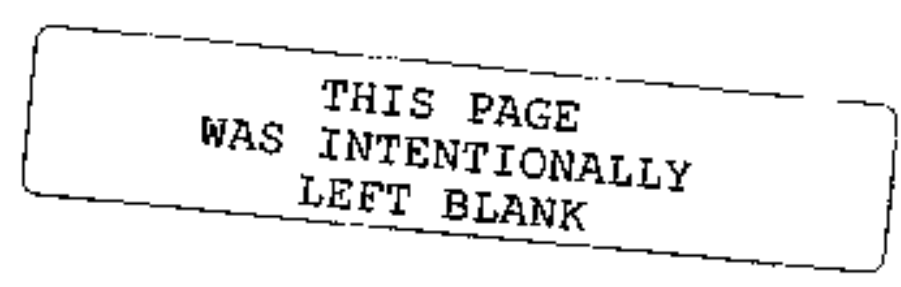




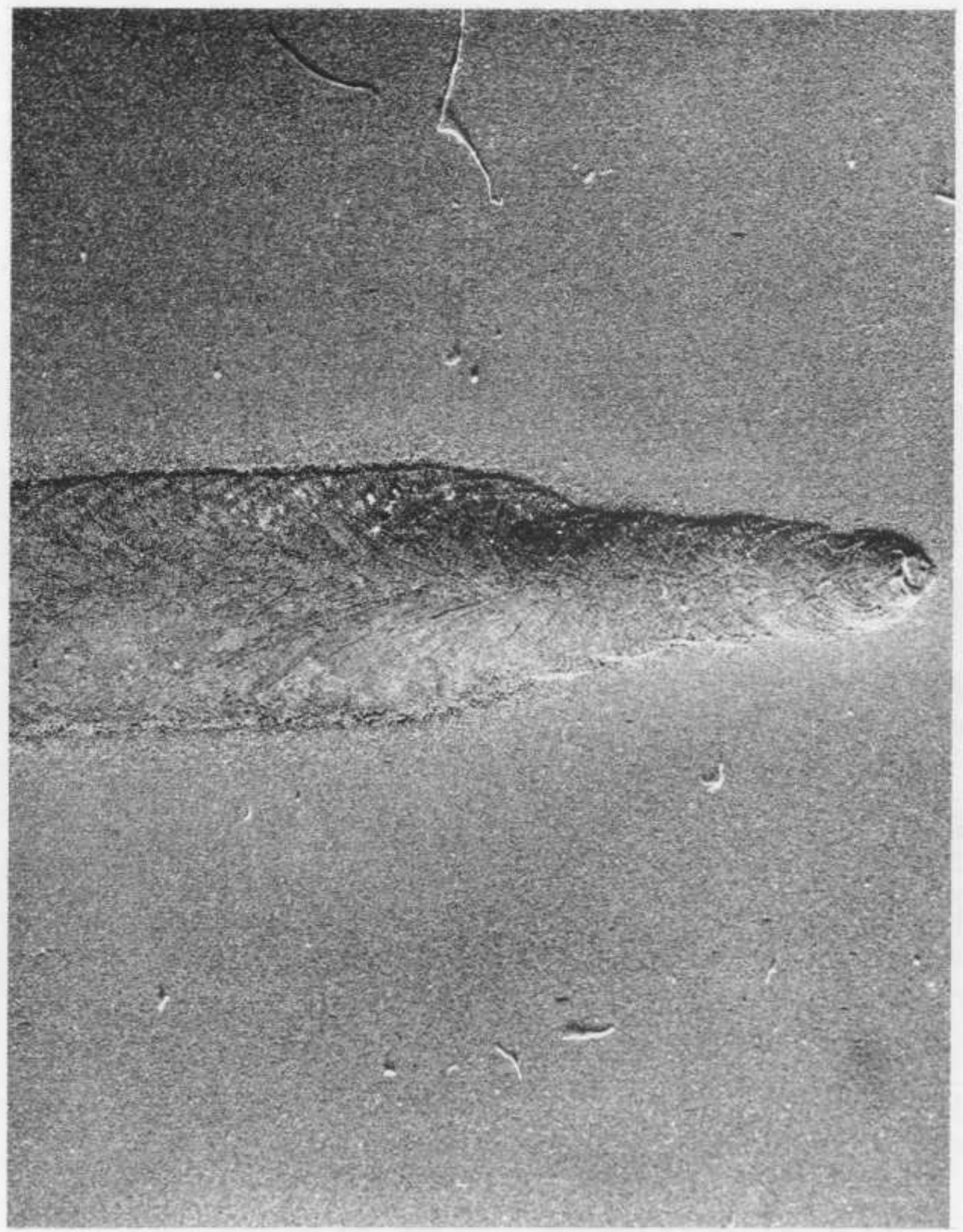

Fig. 4.8 - Pitting at Edge of Weld after Huey Test (15X) 


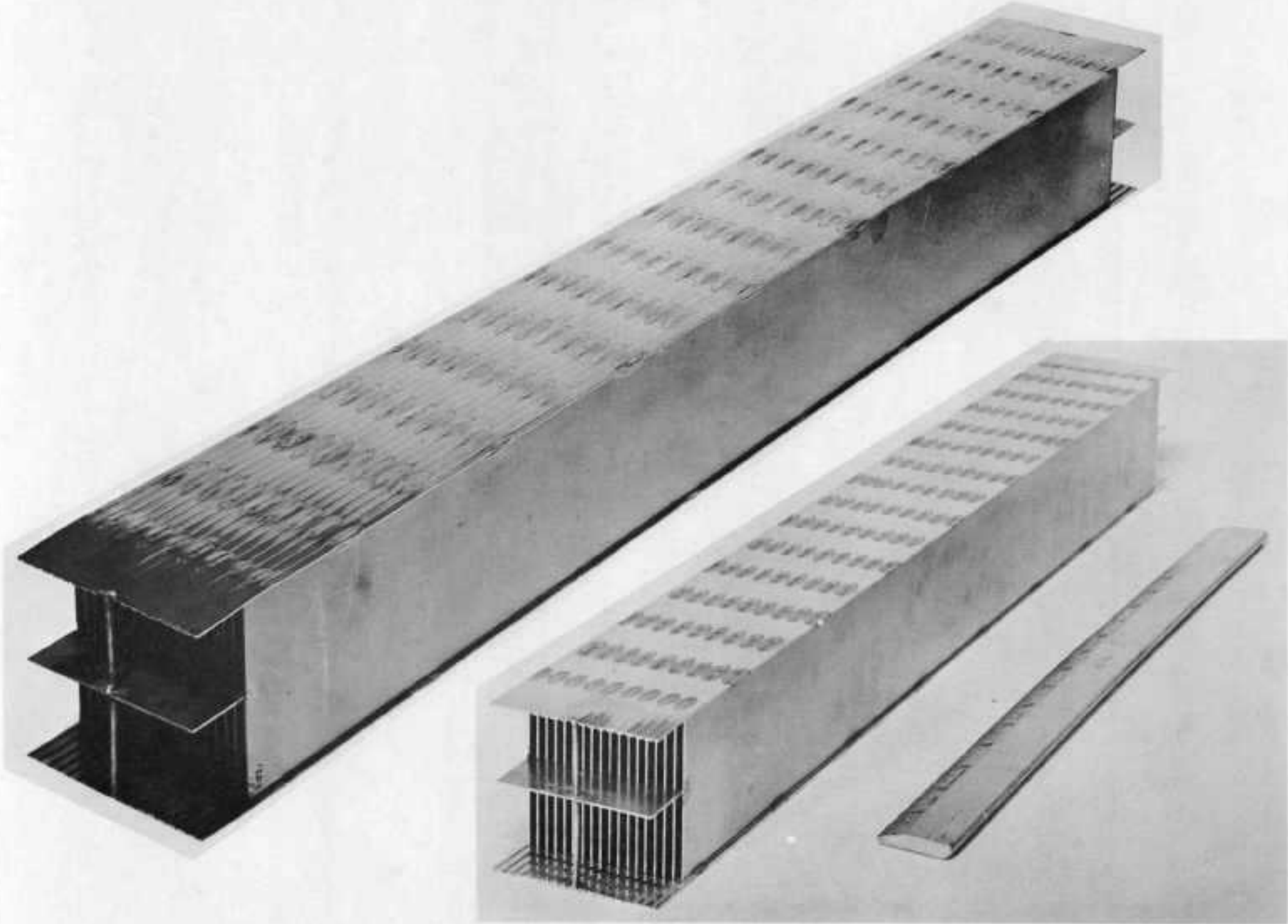

Fig: 4. 9 - Before (Insert) and after Appearance of Dynamic Test Specimen 


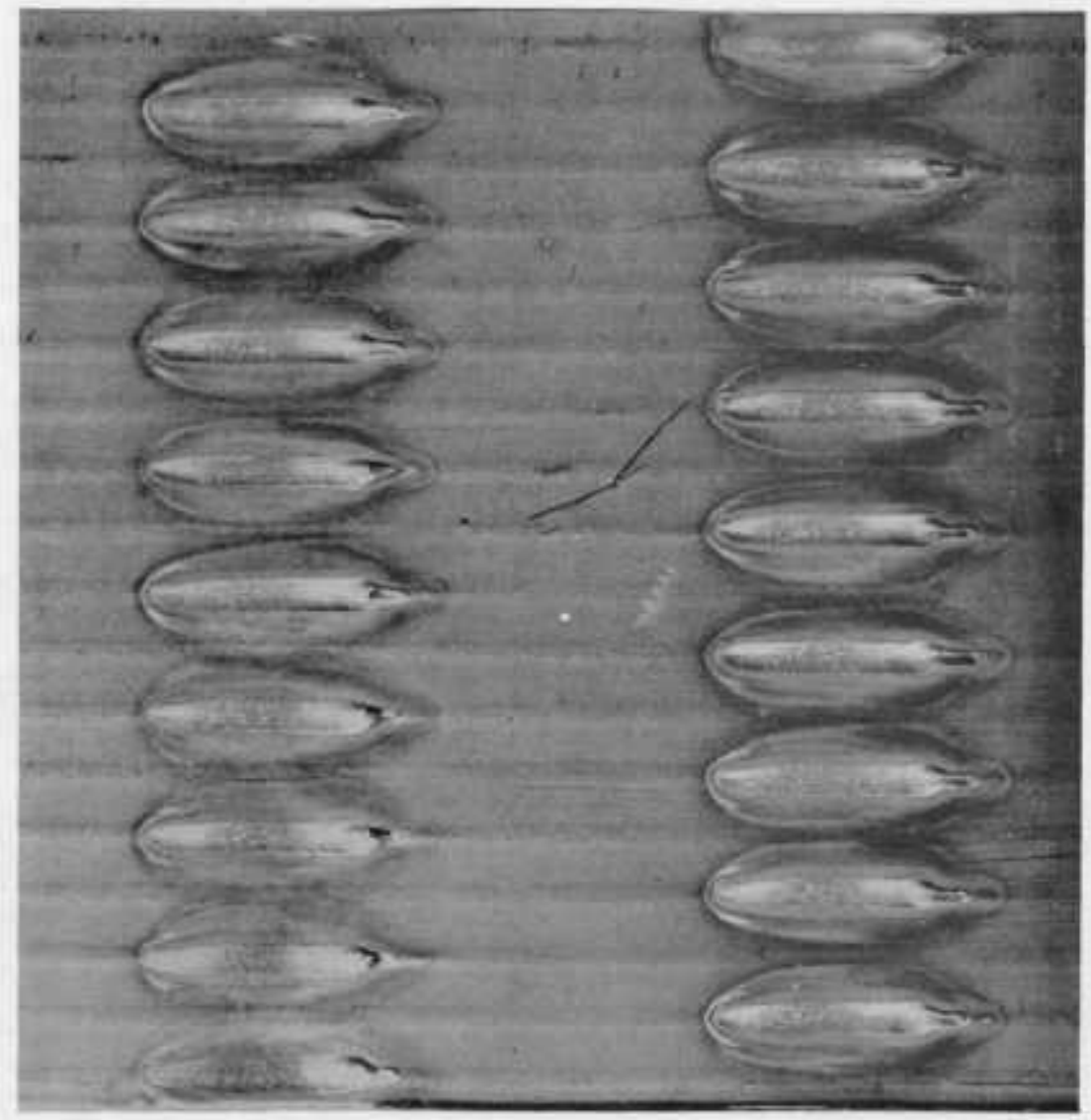

FLOW

Fig. 4. 10 - Post-Test of Welds showing Slight Etching of Middle Third of Weld (2X) 
THIS PAGE

WAS INTENTIONALLY

LEFT BLANK 
TABLE 4. I

ANALYSES OF SPACIGG WBASURPAENT AFTER THREE THEFMAL CYCLES*

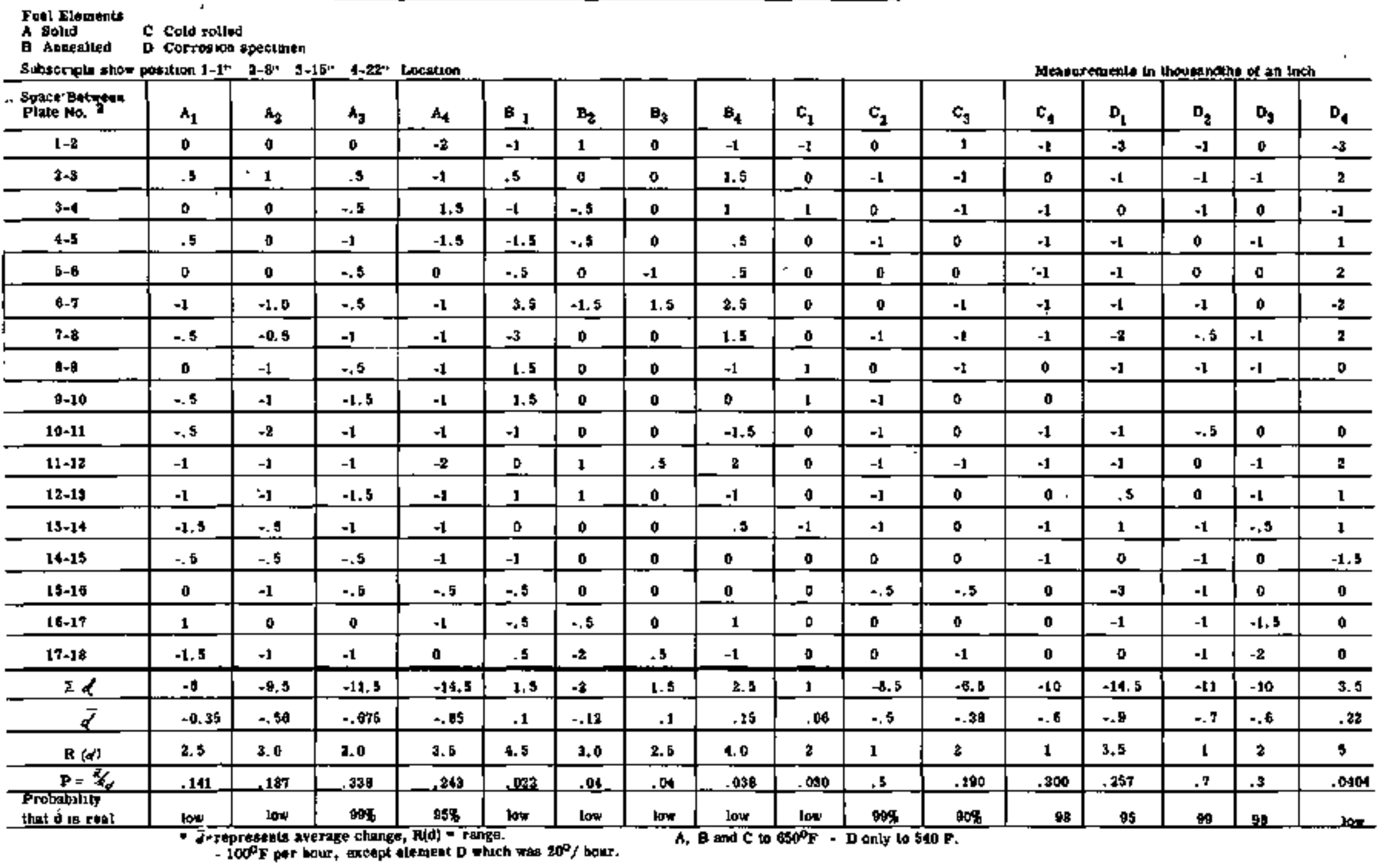


THIS PAGE

WAS INTENTIONALIY

LEET BLANK 


\section{TABLE 4.2 SPECTROSCOPIC ANALYSIS OF LOOP SOLIDS}

Elemental

Constituent

as

$\mathrm{w} / \mathrm{O}$

Co

none detected

Ni

Ni 0

2. 9

$\mathrm{Cr}$

Cr. $0_{3}$

0.9

$\mathrm{Cu}$

trace

Si

Si $0_{2}$

51.4

Mn

$\mathrm{Mn}_{3} \mathrm{O}_{4}$

6. 7

, Fe

$\mathrm{Fe}_{2} \mathrm{O}_{3}$

31. 2

B

$\mathrm{B}_{2} \mathrm{O}_{3}$

6.4

Na

trace.

The relatively large boron concentration led to an investigation of possible sources. Its presence in the detergent used to clean the test loop should not have caused so high a level because the bypass purification loop was operating during the entire test. Nevertheless, the detergent was analyzed and found boron free. An analysis of the side plate, cladding and core gave the following results:

Sample

side plate

$11-\mathrm{D}-19$

11-D-19

9-D-2

Commercial 947
Area

$-$

dead end

core

core

The actual source of the boron was not found,but it is doubtful that the boron came from corrosion of the fuel plates. For this reason it is not believed to be of significance for the purpose of this corrosion study. 


\section{4 CONCLUSIONS}

1. The expected resistance of type $347 \mathrm{ss}$ to general surface corrosion in the SM-2 coolant was confirmed.

2. No evidence of crevice corrosion was found in TIG welds.

3. Sound TIG welds are resistant to cracking by stress corrosion or submerged thermal cycling. Sound welds do not show significant corrosion under static or dynamic exposure to simulated \$M-2 coolant.

4. The chemical cleaning methods given elements 1 and 3 had no detectable effects on corrosion of welds.

\subsection{RECOMMENDATIONS}

1. Welds repaired by rewelding have not received study and should be corrosion tested although increased susceptibility to corrosion is not expected.

2. Should significant changes in welding conditions become desirable, additional corrosion testing should be undertaken. Emphasis should be placed on post-test examination to determine if pitting attack possibly occurs at the weld zone boundary.

3. A long term (1500-hr) dynamic corrosion test with perlodic thermal cycling is desirable to confirm the corrosion resistance found during the relatively short $500-\mathrm{hr}$ test reported herein. 


\section{APPENDIX I}

Typical Composition of Type 347 Stainless Steel Utilized in This Study.

Chromium

W/o

18.2

Nickel

10.5

Columbium*

0.56

Carbon

0.04

Manganese

1.55

Silicon

0.4

Phosphorus

0.025

Sulphur

0.009

* Ta may be substituted for part of the $\mathrm{Cb}$. 
THIS PAGE

WAS INTENTIONALIY

LEFT BLANK : 


\section{BLBLIOGRAPHY}

1. Depaul, D. T., editor, "Corrosion and Wear Handbook for Water Cooled Reactors," TID-7006, March 1957, pp. 17, 32-35.

2. Hoover, H. L., project engineer, "SM-2 .Core and Vessel Design Analysis (Draft)," APAE No. 69, Vol. 1,'pg. 8, August 11, 1960.

3. Richman, R. B., "Stress, Crevice, Galvanic and Uniform Corrosion of Austenitic Stainless Steels and Carbon Steels in High Temperature Boiler Feed Water, A Literature Review, "HW 54879, February 1958, p. 1.

4. Berry, W. E., et al., "The Corrosion of Inconel in High Purity Water Phase II, " Battelle Memorial Institue, December 1958, p. 4.

5. Mason, H., "Selection and Application of Materials for PWR Reactor Plant," WAPD-PWR-971, July 1957, p. 4.

6. Richman, R. B., loc. cit. p. 3.

7. Uhlig, H. H., editor, "The Corrosion Handbook, "John Wiley and Sons, New York, 1948, p. 174.

\section{ACKNOWLEDGMENT}

The work of Mr. L. E. Phillips, who conducted the Phase I testing, is acknowledged. 